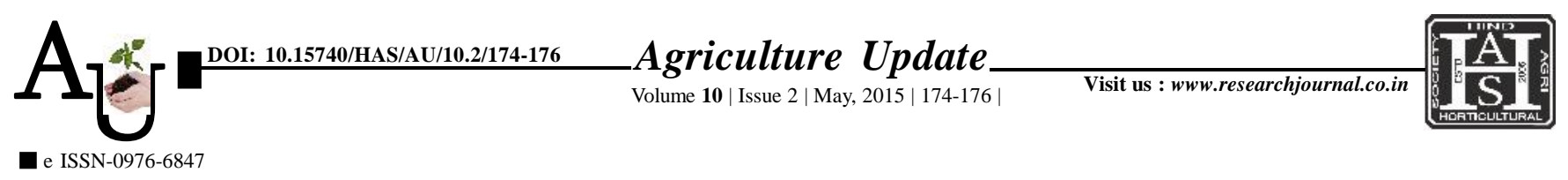

\title{
Research Note: Assessment on the cauliflower based intercropping system on system productivity in Tripura
}

SUBHRA SHIL* AND DIPAK NATH

Article Chronicle: Received :

18.03.2015;

Accepted :

25.04.2015

KeY Words: Intercropping, Sole cropping, Land equivalent ratio (LER), Pea, Cauliflower

Author for correspondence :

\section{SUBHRA SHIL}

Krishi Vigyan Kendra, WEST TRIPURA (TRIPURA) INDIA

Email: spd020@yahoo.

co.in

See end of the article for authors' affiliations
SUMMARY : Intercropping is being adopted as a method of crop production by the farmers of Tripura. Farmers often intercrop legumes with non-legumes. A study was conducted in the farmer's field of Khowai district of Tripura during 2014. The objective of the study was to assess the productivity of cauliflower (Brassica oleracea) and pea (Pisum sativum) in sole and intercropping system to find the best combinations which yield highest production. Cauliflower and pea were planted under four different row arrangements $\left(T_{1}-\right.$ Cauliflower as sole crop, $T_{2}$ - Pea as sole crop, $T_{3}$ - Cauliflower: pea (1:1), $T_{4}-$ Cauliflower: pea (1:2) in the open field. Land equivalent ratio (LER) was calculated to identify the best system of intercropping and it was recorded that incase of $\mathrm{T}_{4}$ i.e., Cauliflower: Pea (1:2) LER was greater than one i.e., 1.04, indicating that this cropping system is profitable in terms of land utilization. Moreover, results of analyses using benefit-cost ratio showed that the most favourable mix of vegetables which could be recommended for adoption to farmers was the intercrop of a row of cauliflower with two rows of Pea $\left(\mathrm{T}_{4}-1: 2\right)$.

How to cite this article : Shil, Subhra and Nath, Dipak (2015). Assessment on the cauliflower based intercropping system on system productivity in Tripura. Agric. Update, 10(2): 174-176. 